\title{
Spectral behavior of some modal soil profiles from São Paulo State, Brazil
}

\author{
José Alexandre Melo Demattê ( $\left.{ }^{1}\right)$; Fabrício da Silva Terra $\left({ }^{1 *}\right)$; Carlos Fernando Quartaroli ( $\left.{ }^{2}\right)$ \\ (') Universidade de São Paulo (USP), Escola Superior de Agricultura “Luiz de Queiroz” (ESALQ), Departamento de Ciência do Solo \\ (LSO), Caixa Postal 9, 13418-900 Piracicaba (SP), Brasil. \\ (2) Embrapa Monitoramento por Satélite, Av. Soldado Passarinho, 303, Fazenda Chapadão, 13070-115 Campinas (SP), Brasil. \\ (*) Corresponding author: terra.fabricio@gmail.com
}

Received: Jan. 10, 2012; Accepted: Sep. 5, 2012

\begin{abstract}
Remote sensing has a high potential for environmental evaluation. However, a necessity exists for a better understanding of the relations between the soil attributes and spectral data. The objective of this work was to analyze the spectral behavior of some soil profiles from the region of Piracicaba, São Paulo State, using a laboratory spectroradiometer (400 to $2500 \mathrm{~nm}$ ). The relations between the reflected electromagnetic energy and the soil physical, chemical and mineralogical attributes were analyzed, verifying the spectral variations of soil samples in depth along the profiles with their classification and discrimination. Sandy soil reflected more, presenting a spectral curve with an ascendant form, opposite to clayey soils. The $1900 \mathrm{~nm}$ band discriminated soil with 2:1 mineralogy from the 1:1 and oxidic soils. It was possible to detect the presence of kaolinite, gibbsite, hematite and goethite in the soils through the descriptive aspects of curves, absorption features and reflectance intensity. A relation exists between the weathering stage and spectral data. The evaluation of the superficial and subsuperficial horizon samples allowed characterizing and discriminating the analytical variability of the profile, helping to soil distinguishing and classification.
\end{abstract}

Key words: soil reflectance, soil attributes, soil classification.

\section{Comportamento espectral de alguns perfis modais de solos do Estado de São Paulo, Brasil}

\section{Resumo}

O sensoriamento remoto representa um importante potencial na avaliação do ambiente, contudo, ainda existe a necessidade de entender melhor as relações entre atributos do solo e dados espectrais. O objetivo do trabalho foi analisar descritivamente o comportamento espectral de alguns perfis de solos da região de Piracicaba, Estado de São Paulo, utilizando o espectrorradiômetro de laboratório (400 a 2500 nm). Procurou-se ainda, avaliar as relações entre energia eletromagnética refletida com atributos químicos, físicos e mineralógicos dos solos, verificando as variações espectrais das amostras ao longo dos perfis e suas relações com classificação e discriminação dos solos. Observou-se que solos mais arenosos refletiram mais, com curvas espectrais de aspecto ascendente, ao contrário dos solos argilosos. A banda centrada em $1900 \mathrm{~nm}$ discriminou solos com mineralogia 2:1 dos de 1:1 e oxídicos. Foi possível detectar a presença de caulinita, gibbsita e dos óxidos de ferro (hematita e goethita) presentes nos solos pelos aspectos descritivos das curvas, feições de absorção e intensidade de reflectância; e que existe uma relação entre níveis de intemperismo e informações espectrais. A avaliação dos dados espectrais de amostras dos horizontes superficiais e subsuperficiais permitiu caracterizar e discernir a variabilidade analítica do perfil, auxiliando na discriminação e classificação dos solos.

Palavras-chave: reflectância do solo, atributos do solo, classificação do solo.

\section{INTRODUCTION}

The soil spectral behavior is determined by the cumulative property resulting from the intrinsic spectral behavior of the heterogenic combinations of mineral and organic material and their humidity (STONER and Baumgardner, 1981). Thus, by examining the spectral reflectance, it is possible to obtain valuable information about the physical and chemical attributes of the soils. The possibility to identify the spectral variations, normally linked to specific absorption phenomena, makes the reflectance spectroscopy an important tool in the study of soil composition in the laboratory, field or through satellite images (Madeira Netto, 1996; DemattÊ et al., 2004).

The high number of scientific papers published in the area of applied remote sensing points out the great capacity of the reflectance spectroscopy technique in determining some chemical, granulometric and/or mineralogical elements, and the sensitivity in measuring the organic and inorganic phases of the soil, confirming that its use in agricultural and environmental sciences is particularly 
relevant (SORENSEN and DalsGaARD, 2005; Cozzolino and Morón, 2006; Viscarra Rossel et al., 2006).

On the other hand, it is important to move ahead in the studies of spectral behavior of soil attributes that contribute to the development of more accurate and rapid techniques that enable mapping of the spatial variability of soils in extensive areas. The study of soil attributes through remote sensing can assist in soil survey and mapping techniques, as well as prediction of the erosion and a more accurate fertilizing management practices (SHEPARD and Walsh, 2002; OdLare et al., 2005).

The hypothesis of this study is based on the interaction between electromagnetic energy with organic and inorganic components of the soil, which amounts, compositions and distinct structures form different reflectance curves, permitting its detection and discrimination. So, the objective of this study is to analyze the relation between the reflected energy and the physical, chemical and mineralogical attributes of the soils from the region of Piracicaba, São Paulo State, further to determine the spectral variations of the soil samples along a profile and a toposequence, as well as to evaluate the potential of the descriptive spectral analyses in the discrimination of these soils.

\section{MATERIAL AND METHODS}

\section{Description of the study area}

The study area is localized in the municipality of Rafard, region of Piracicaba, State of São Paulo, between the latitudes $22^{\circ} 58^{\prime} 56^{\prime \prime} S$ and $23^{\circ} 00^{\prime} 33^{\prime \prime} S$ and longitudes $47^{\circ} 37^{\prime} 55^{\prime \prime} \mathrm{W}$ and $47^{\circ} 39^{\prime} 32^{\prime \prime} \mathrm{W}$, comprising an area of approximately 198 acres bordering the Capivari river, with altitudes varying between 475 and 567 meters. The climate is of Cwa-type, according to the Köppen classification.

The region is located in the geotectonic unit called Parana Basin and the physiographic unit called Paulista peripheral depression. The regional geology is dominated by the Itararé Formation, dated as the Upper Carboniferous to Mid Permian, which manifests as a complex association of different detritic lithofacies that succeed one another vertically and horizontally. The predominant lithologies are heterogenically granulated sandstones, mineralogically immature, that transform into feldspathic sandstones. The formation also contains diamictite with clasts of various lithologies, forms and dimensions; rhythmic sediments, generally referred to as varvite; conglomerates and conglomeratic sandstones; siltstones, argellites and shales. There are further occurrences of basic eruptive rocks (diabase) that form intrusive bodies of dykes and sills with the same composition as the tholeiitic basalts in the Serra Geral Formation from the Jurassic-Cretaceous (Almeida and Melo, 1981).

\section{Location of the profiles}

The choice of the sampling sites in the relief was based on observations and studies of the planialtimetric maps, aerial photographs and field observations. A digital elevation model (DEM) was made that permitted a general view of the landscape, which facilitated marking out the points. The model was made from the contour lines that were digitalized from the topographic maps and simplified by Douglas-Peucker's algorithm with an isoline and breakline tolerance of 2 meters. The triangular irregular network (TIN) was chosen, using Delaney's modified triangulation as criteria, which gave a more authentic representation of the terrain, avoiding smoothening of features such as valleys and ridges.

\section{Soil analyses}

A morphological description of the seventeen soil profiles from the different locations in the landscape was made. The positions of the profiles were georeferenced with a GPS (Global Positioning System) with post-processing differential correction of the data.

The soil samples were collected and separated from each horizon or layer detected in the morphological description. The sampling depths varied between $0-20 \mathrm{~cm}$ for the superficial horizons and $40-60 \mathrm{~cm}$ for the subsuperficial horizons. The samples were dried under forced air in a temperature of $45^{\circ} \mathrm{C}$ for 48 hours, then weighed, crushed and sieved. Fractions smaller than $2 \mathrm{~mm}$ were separated in sub-samples and subjected to granulometric, chemical, mineralogical and radiometric analyses. Fractions above $2 \mathrm{~mm}$ were washed in running water and separated through $20 \mathrm{~mm}$ sieves for determination of the amount of pebbles and gravel.

The soil colors were determined in the laboratory through a Minolta CR300 colorimeter, programmed for readings according to the Munsell system. Mottle colors and variegated horizons were evaluated in the field using Munsell color chart.

The chemical analyses were done using the method of CAMARgo et al. (1996), comprising of $\mathrm{pH}$ determination in water, $\mathrm{KCl} 1 \mathrm{~N}$ and $\mathrm{CaCl}_{2}$; determination of exchangeable bases $\left(\mathrm{Ca}^{++}, \mathrm{Mg}^{++}, \mathrm{K}^{+}\right)$; sum of bases $(\mathrm{SB})$; cation exchange capacity (CEC); exchangeable aluminum $\left(\mathrm{Al}^{3+}\right)$; base saturation percentage; aluminum saturation percentage; potential acidity $\left(\mathrm{H}^{+}+\mathrm{Al}^{3+}\right)$; assimilable phosphorus; organic matter and organic carbon; amounts of $\mathrm{Fe}_{2} \mathrm{O}_{3}$, $\mathrm{SiO}_{2}$ and $\mathrm{Al}_{2} \mathrm{O}_{3}$ through sulfuric acid attack and further calculation of the Ki index.

The granulometric analyses were done using the densimeter method (CAMARGO et al., 1996), separating sand, silt and clay fractions, using $0.1 \mathrm{~N}$ calcium hexametaphosphate and $0.1 \mathrm{~N}$ sodium hydroxide as dispersing 
agents. The sand was separated into five fractions: very coarse sand $(2-1 \mathrm{~mm})$, coarse sand $(1-0.5 \mathrm{~mm})$, medium sand $(0.5-0.25 \mathrm{~mm})$, fine sand $(0.25-0.1 \mathrm{~mm})$, and very fine sand $(0.1-0.05 \mathrm{~mm})$. The textural classification was done according to the soil texture triangle of the United States Department of Agriculture (USDA).

The mineralogical analyses of the silt and clay fractions were done using the method demonstrated by Moore and Reynolds (1997), in which the crystallographic properties are analyzed through the powder method, without chemical treatment at $25^{\circ} \mathrm{C}$. The samples were X-rayed with Philips equipment. A file containing information regarding the difratometry was produced for each sample. These files were then compared with existing X-ray diffraction patterns in a database. After the identification, the presence or absence of certain minerals was determined for each sample.

The soils were classified according to the Soil Taxonomy (SoIl Survey Staff, 2010) and Brazilian Soil Classification System (EMBRAPA, 2006).

\section{Spectral data acquisition}

The spectral data was obtained through the Infra-Red Intelligent Spectroradiometer - IRIS with resolution of $2 \mathrm{~nm}$ in the range of 400 to $1,000 \mathrm{~nm}$ and $4 \mathrm{~nm}$ between 1,000 and 2,500 $\mathrm{nm}$. The samples were placed in Petri dishes with $9 \mathrm{~cm}$ diameter and $1.5 \mathrm{~cm}$ height and distributed so that the surface became as smooth as possible. The geometry for the data acquisition followed the procedures set by Demattê and GARCIA (1999). A white dish with 100\% reflectance was used as absolute reference. Three readings were done for each sample, turning the Petri dish $120^{\circ}$ for each reading so that all the points of the sample were covered.

The ratio between the spectral radiant flux reflected by the sample surface and the flux reflected by the reference dish under the same geometric conditions resulted in the bidirectional reflectance factor. The spectral radiant flux used in the calculation of the reflectance factor was determined by the arithmetic mean of the three readings.
All spectral data were passed through a filtering system to eliminate the systematic noise from the device and were shown in graphs were the reflectance factor was plotted against the wavelength resulting in the spectral curves. For subsequent comparisons, these curves were clustered according to the methodology of ForMAGGio et al. (1996), where four soil spectra standards were identified depending on the shape of the curve and the intensity of the influence of the following parameters: amount of iron oxide, amount of organic matter and parent material (Table 1 and Figure 1).

\section{RESULTS AND DISCUSSION}

\section{Characterization of the main studied soils}

The distribution of the soil profiles in the landscape can be observed in the digital elevation model (Figure 2). The data of the chemical and physical analyses, as well as the soil classification of the seventeen profiles, are presented in table 2.

The Typic Hydraquent (Gleissolo Háplico Ta Distrófico típico - GXvd) (Profile 1), moderately deep soil, is found in the slightly flat (5\% slope) relief region in the lowlands (Figure 2), with sandstone as parent material and constantly suffering the influence of the ground water table. Gleyzation could be seen from the Bg horizon, indicating low permeability. Chemically, this profile is dystrophic, however, there is clay that consists of 2:1 minerals as well, bearing in mind the high ki results of 3.43 (Table 2).

The physical results for Profile 2 show an elevated textural contrast between the superficial and subsuperficial horizons, with the clay content increasing from $100 \mathrm{~g} \mathrm{~kg}^{-1}$ to $220 \mathrm{~g} \mathrm{~kg}^{-1}$, showing evidence of an abruptic character (Table 2). The chemical results showed a base saturation below 30\%; on the other hand, the aluminum saturation was extremely high, allowing the soil to be classified as Typic Haploxerult (Argissolo Vermelho-Amarelo Ta Distrófico abrúptico - PVAvd). The CEC characterizes a colloidal complex of high activity with evidence of

Table 1. Characteristics of the four standards of spectral curves

\begin{tabular}{|c|c|c|c|c|}
\hline \multirow{2}{*}{ Attribute } & \multicolumn{4}{|c|}{ Type } \\
\hline & 1 & 2 & 3 & 4 \\
\hline Albedo & $\begin{array}{c}\text { Low } \\
( \pm 15 \%)\end{array}$ & $\begin{array}{c}\text { variable } \\
\text { (20 to } 50 \%)\end{array}$ & $\begin{array}{c}\text { medium } \\
\text { (30 to } 40 \%)\end{array}$ & $\begin{array}{c}\text { medium } \\
\text { (30 to } 40 \%)\end{array}$ \\
\hline Shape & horizontal flat & arched (rounded) & arched (linear) & flat and inclined \\
\hline Absorption features & $\begin{array}{c}450 \text { and } 900 \mathrm{~nm} \\
\text { (wide) } \\
1,400 ; 1,900 ; 2,200 \mathrm{~nm} \\
\text { (slightly narrow) }\end{array}$ & $\begin{array}{c}\text { 450, } 650 \text { and } 900 \mathrm{~nm} \\
\text { (wide) } \\
\text { 1,400; } 1,900 ; 2,200 \mathrm{~nm} \\
\text { (very narrow) }\end{array}$ & $\begin{array}{l}\text { features } \\
\text { absent }\end{array}$ & $\begin{array}{c}900 \mathrm{~nm} \\
\text { (slightly wide) } \\
1,400 ; 1,900 ; 2,200 \mathrm{~nm} \\
\text { (slightly narrow) }\end{array}$ \\
\hline Visible/NIR & $\begin{array}{l}\text { inflection at } 650 \mathrm{~nm} \\
\text { color red }\end{array}$ & $\begin{array}{l}\text { no inflection } \\
\text { just inclination } \\
\text { color yellow }\end{array}$ & $\begin{array}{c}\text { wide } \\
\text { color grey }\end{array}$ & $\begin{array}{l}\text { inflection at } 650 \mathrm{~nm} \\
\text { color red }\end{array}$ \\
\hline
\end{tabular}

Source: Formaggio et al. (1996). 


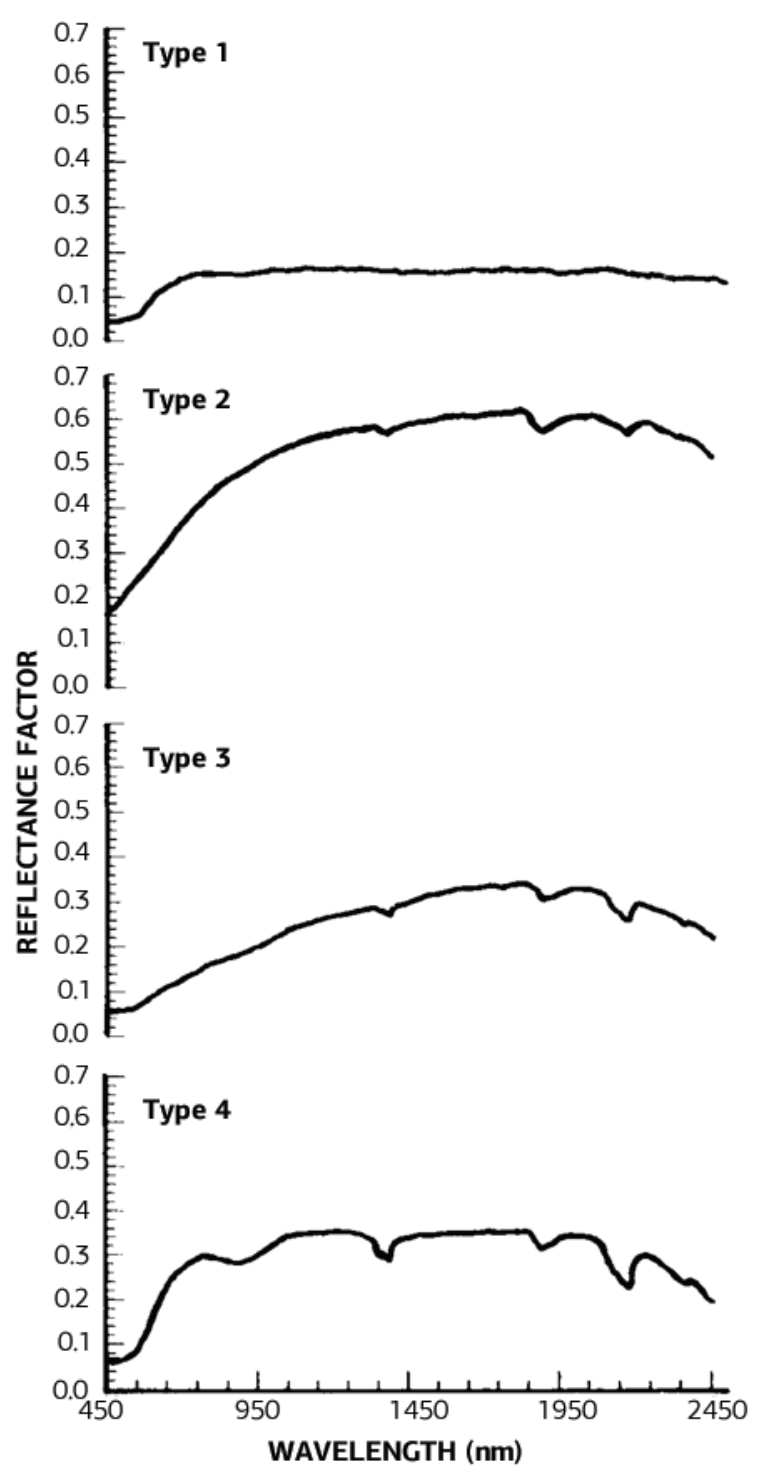

Figure 1. Types of soil spectral behavior according to Formaggio et al. (1996).

a mixed mineralogy. As this soil is moderately deep, the degree of weathering is not so pronounced, as could be seen from the ki index values above 2.4 .

It was observed in the slope regions the presence of deep soils that converge into shallow and stony soils, which is the case of Lithic Dystrustept (Cambissolo Háplico Ta Eutrófico típico - CXve) (Profile 3) (Figure 2) which data indicate a small textural gradient (Table 2). The presence of small fragments of parent material, shales in this case confirmed by the silt content - is common in the mass of the incipient $\mathrm{B}$ horizon. It is characterized by an elevated base saturation in both horizons and high activity clay. Due to the high ki value (5.24) in the B horizon, it can be inferred that the 2:1 mineralogy is predominant. This is the least weathered soil of all.

The Profile 4 (Kandiudalfic Eutrudox/Nitossolo Vermelho Eutroférrico latossólico - NVef) is a deep soil, well drained and situated on a flat area on the top of a slope (Figure 2). The texture varies from clay to heavy clay. It shows high fertility, with base saturation above $65 \%$. The ki index in the subsuperficial horizon is below 2.0 , which characterizes a soil with low activity clay, as confirmed by CEC values (Table 2). The mineralogy is mainly constituted by kaolinite and iron oxides, which is reflected by the $\mathrm{Fe}_{2} \mathrm{O}_{3}$ content and the parent material represented by basic rocks.

The Profile 9 (Lithic Udipsamment/Neossolo Regolítico Distrófico típico - RRd), with sandstone as parent material, has a massive aspect in depth with the two first horizons of sandy texture. The chemical results indicate a low base saturation and ki indexes close to 2.0 (Table 2).

Similar to the fourth profile, even with respect to the elevated values of base saturation, total iron content and ki index, the Profile 16 was classified as Kandiudalfic Eutrudox (Nitossolo Vermelho Eutrófico latossólico - NVe).

The morphological characteristics of Typic Haploxerult (Argissolo Amarelo Eutrófico abrúptico - PAe) (Profile 17) indicate a deep soil with moderate drainage occurring in an undulating relief (Figure 1). The horizon of the sub-surface shows an accentuated textural gradient characterizing a $\mathrm{Bt}$ with high base saturation, thus eutrophic, with low activity clay and a ki around 1.8, indicating a mixed mineralogy with kaolinite and oxides (Table 2).

\section{Soil spectral reflectance}

The Typic Hydraquent (GXvd) in profile 1 shows typical spectral curves of soils with high sand content, given by the high reflectance intensity around 0.6 (Figure 3a). As the reflectance is high for quartz and low for organic matter, removal of the organic matter exposes more quartz, which results in an increase of the reflectance intensity. A weak concavity in the absorption feature at $850 \mathrm{~nm}$ in both horizons, associated with the bright colors indicate the lowest presence of iron oxides, such as hematite (Fontes and Carvalho, 2005), as confirmed by the analyses. The low iron contents produce higher reflectance intensities (Demattê et al., 2003). With respect to the curves determined by Formaggio et al. (1996), all the soil sample curves along the profile resemble type 2 (Table 1 and Figure 2). However, they are different when their shapes are analyzed in detail. The curve regarding the superficial layer shows a positive tendency, while the subsuperficial curve has a flat tendency (Figure 3a). Such curves show a slightly straight shape, with a small concavity in the $700 \mathrm{~nm}$ range.

The Typic Haploxerult (PVAvd) from the second profile, developed over stratified sandstones, shows a similar spectral curve behavior in all subsuperficial layers, with high reflectance intensity, especially in horizon CR1 with $73 \%$, and strong absorption features at 


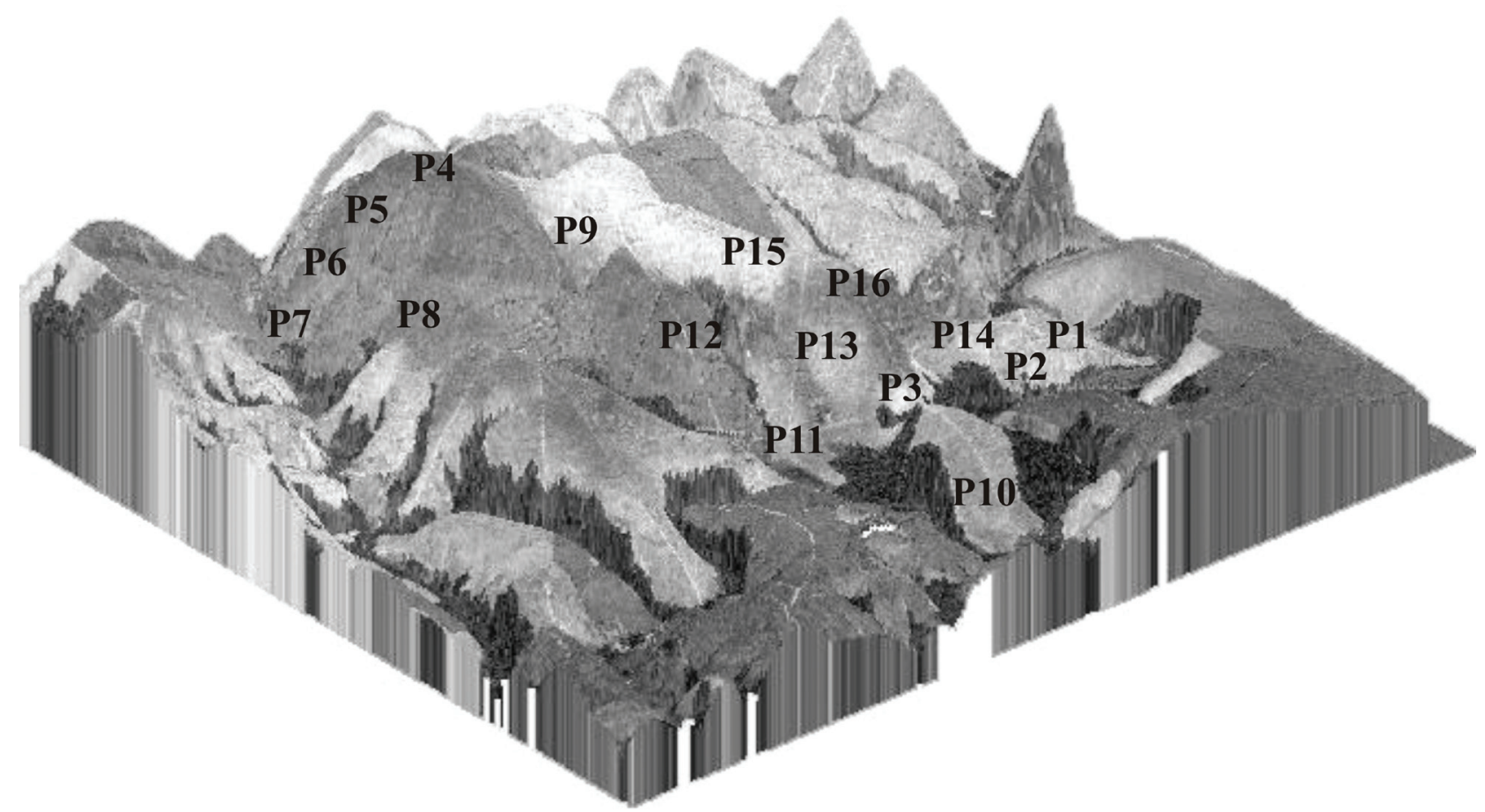

Figure 2. Distribution of the soil profiles in the study area using digital elevation model (DEM).

1,400 and $1,900 \mathrm{~nm}$ (Figure 3b) attributed to the $\mathrm{OH}$ - in the soil hygroscopic water (BEN-Dor et al., 2002) and the presence of 2:1 minerals, confirmed by the high ki value (Dематtê et al., 2004), and at 2,200 nm, caused by the $\mathrm{OH}-$ groups of the clay minerals. The weak features in the range between 800 and 1,050 nm are caused by the low concentrations of iron oxides (Vitorello and Galváo, 1996). In the Ap horizon there is influence of organic matter with resulting reduction of albedo and smoothening of the absorption features (Demattê and Garcia, 1999). In the superficial layer, the soil from Profile 2 shows a type 2 spectral curve, however, in the subsurface layer one can detect differences that alter the classification into type 4 (Table 1 and Figure 1), characterized by strong absorption features. This confirms the preliminary observations by Demattê et al. (2004) where the curve types separated soil samples from the surface and subsurface layers.

The Lithic Dystrustept (CXve) is the only profile developed over shale with a solum that has a coarser texture of sandy loam nature. The evaluation of the spectral curves showed that the least weathered material gave type 2 curves (Table 1 and Figure 1), with intensive absorption features and patterns similar to those of sandstones and siltstones (Figure 3c). In the Bi and Ap horizons these features are masked by the effect of organic matter. The highest reflectance intensity, around $75 \%$, was found in layer $\mathrm{R}$, followed by the $\mathrm{CR}$ and $\mathrm{C}$ horizons, with wavelengths smaller than $1,900 \mathrm{~nm}$. The samples' yellowish color is confirmed by the absorption features that are characteristic of the goethite, with narrow bands between 450 and $600 \mathrm{~nm}$ and slight concavity between 600 and $750 \mathrm{~nm}$ (Scheinost and Schwertmann, 1999).

Soils that are rich in hematite show a wider concavity between 400 and $600 \mathrm{~nm}$ (Sherman and Waite, 1985), as well as lower reflectance intensity when compared to goethite (Kosmas at al., 1984). This can be observed in Profile 4 (Kandiudalfic Eutrudox / NVef) (Figure 3d). Besides, all horizons show a strong concavity at $850 \mathrm{~nm}$, corroborating the results found by VITORELLO and GALVÃo (1996) and Demattê et al. (2001). The presence of 1:1 minerals, such as kaolinite, can be observed through the typical feature (step) at $2200 \mathrm{~nm}$ (Hauff et al., 1990), later confirmed by Demattê and Garcia (1999). The curves of this profile could be associated with standard type 1 (Table 1 and Figure 1), related to soils derived from basic eruptive rocks, normally heavy clayey with high values of total iron.

The Lithic Udipsamment (RRd), developed over sandstones with clayey cement, shows a spectral behavior different from the previously analyzed profiles. It has spectral curves with high reflectance intensity due to its sandy character (Table 2). There is little difference with regards to the reflectance intensity among the horizons until $1900 \mathrm{~nm}$, where the maximum value is around $60 \%$. After this wavelength it is possible to distinguish the formation of two groups, the horizons Ap1 and Ap2, with high reflectance, and the horizons C1, C2 and $\mathrm{Cr}$, with low reflectance (Figure 4a). The organic matter masked the absorption feature of iron oxide 
Table 2. Results of the chemical and physical analyses of the soil samples: organic matter (O.M; sum of bases (SB); cation exchange capacity (CEC); base saturation (V); aluminum saturation (m); and the molar relationship $\mathrm{SiO}_{2} / \mathrm{Al}_{2} \mathrm{O}_{3}(\mathrm{Ki})$

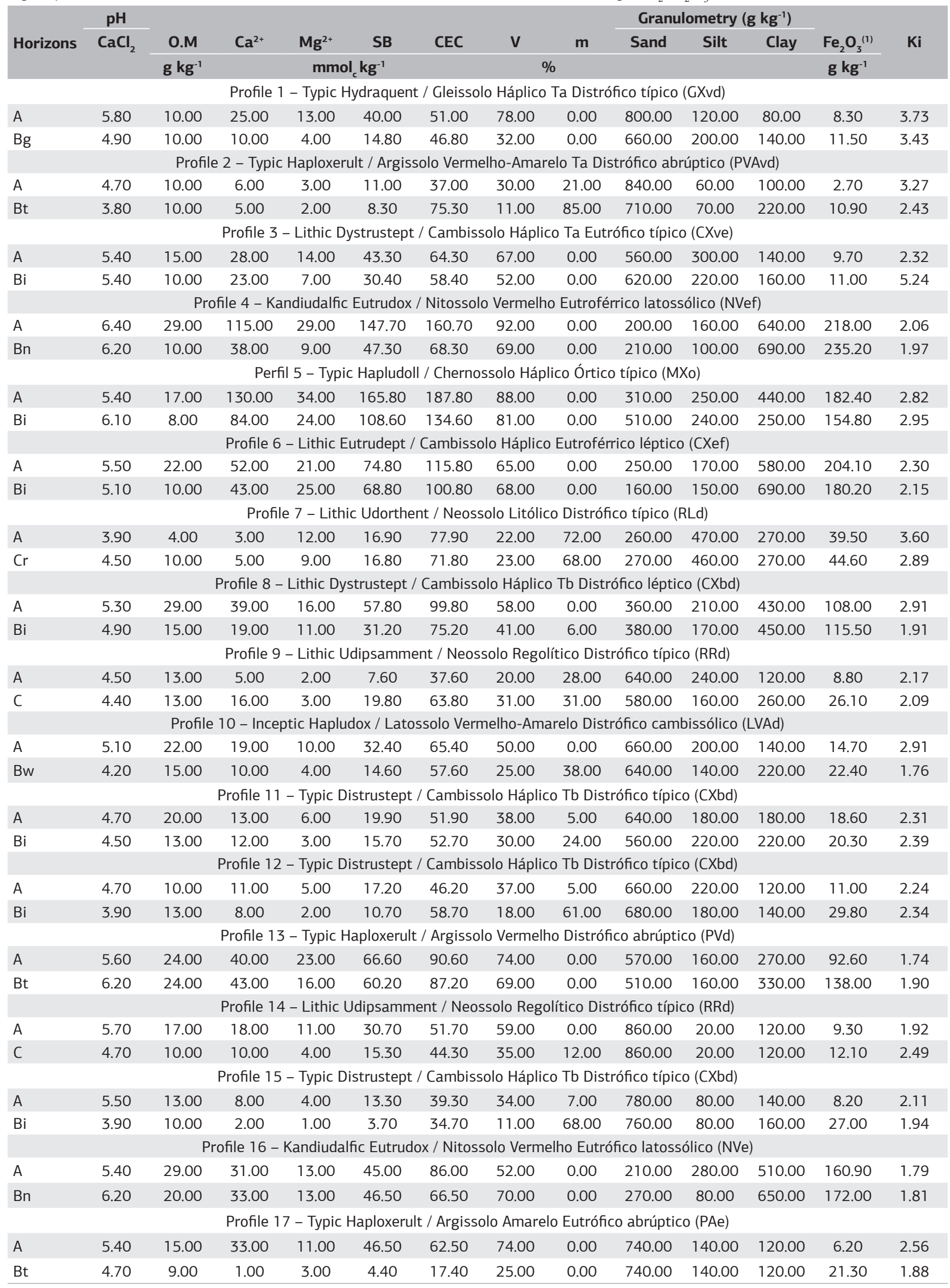

(') Using $\mathrm{H}_{2} \mathrm{SO}_{4}$. 

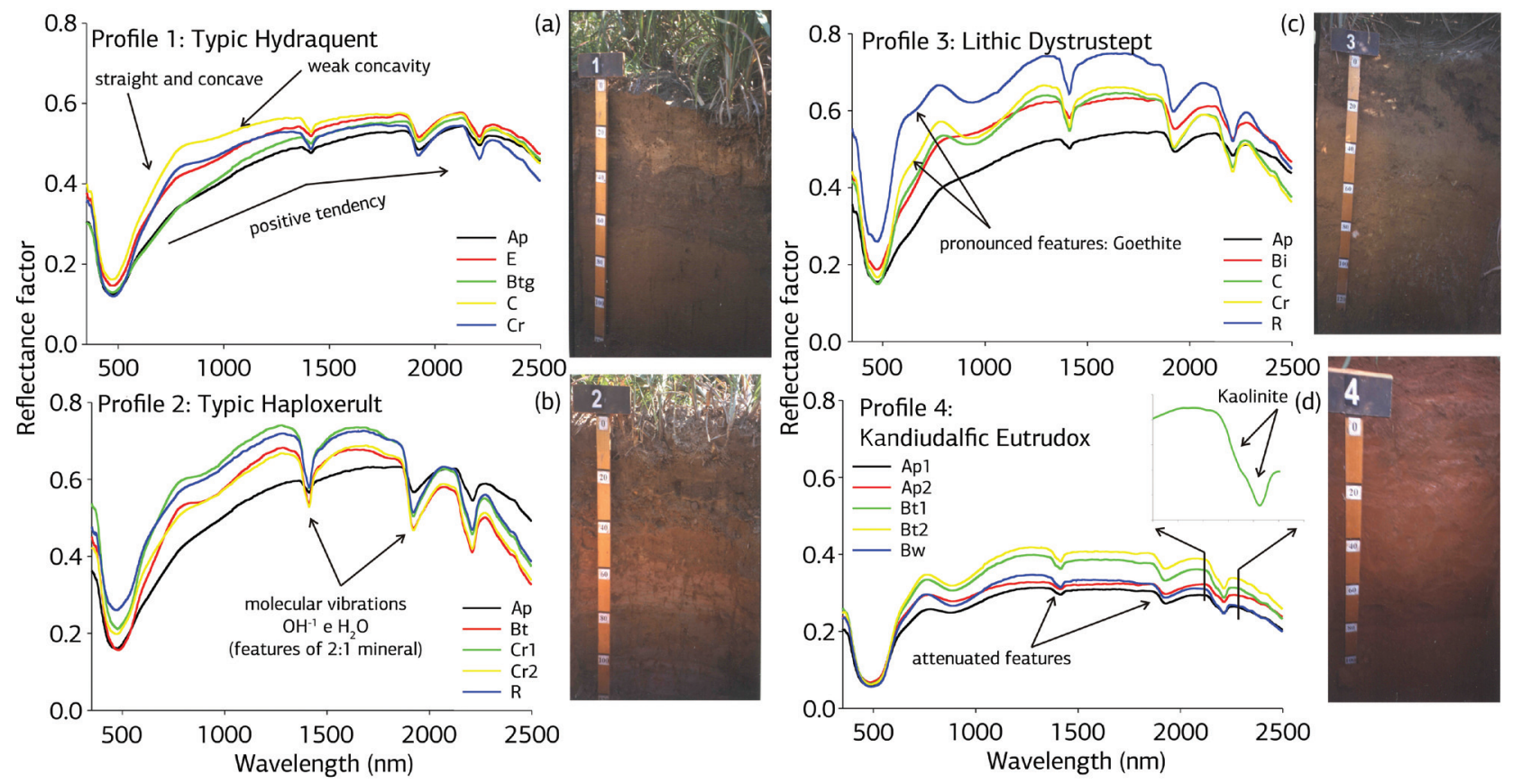

Figure 3. Spectral behavior of the soil classes: Typic Hydraquent (a), Typic Haploxerult (b), Lithic Dystrustept (c) and Kandiudalfic Eutrudox (d), and their respective horizons; Ap: A horizon with pedoturbation (numeric suffixes indicate subdivisions); E: mineral horizon with clay removal; $\mathrm{Bi}, \mathrm{Bw}, \mathrm{Bt}$ and $\mathrm{Bg}$ : incipient $\mathrm{B}$ horizon, with intense alteration, with clay accumulation and gley, respectively; Cr: $\mathrm{C}$ horizon (unconsolidated material) with saprolite (SANTOs et al., 2005).

in the range between 800 and 1,050 nm, making the curves of the A horizons take on a linear aspect in this interval. The features between 450 and $600 \mathrm{~nm}$ cause subtle differences in the absorption intensity, which can be sufficient to separate the subhorizons in the field by their colors. In this range, the deeper horizons show a slightly smaller reflectance factor, which is associated with a bigger proportion of hematite, which in turn makes the horizon more reddish closer to the rock. The spectral curves fit in the type 2 standard for superficial horizons and type 4 for subsuperficial horizons (Table 1 and Figure 1).

Apart from the physical, chemical and morphological attributes, Profile 16 showed spectral curves with a behavior similar to that of Profile 4, with a slight fall in the reflectance factor. The analyses of both profiles revealed agreement with the attributes described by FormagGio et al. (1996) for type 1 curves (Table 1 and Figure 1). A particularity for these profiles is the spectral behavior of the deepest profiles, the oxic $\mathrm{B}$ horizons $(\mathrm{Bw})$, that show reflectance intensities close to or even lower than those of the surface horizons (Figures $2 \mathrm{~d}$ and $3 \mathrm{~b}$ ). The lower reflectance in the superficial horizons is attributed to organic matter, a fact that cannot explain the same behavior in Bw, which more likely is explained by the presence of opaque minerals and a high content of total iron (Table 2) (Demattê et al., 2001). The higher reflectance of the second horizon described in the soil profile (textural horizon/ $\mathrm{Bt}$ ) is probably caused by a sandier texture, resulting from the formation processes of this type of horizon. The spectral feature that can be observed at 2,265 $\mathrm{nm}$, representing the presence of gibbsite (mineral 1:1), is characteristic of weathering tropical soils (MADEIRA NetTo, 1996).

The Typic Haploxerult/PAe (Profile 17), derived from a sandstone, shows an E horizon with bright colors and a sand fraction with high quartz content, resulting in high spectral intensities around 73\% (Figure 4c). The spectral pattern is close to type 4 (Table 1 and Figure 1), with a weak influence of iron oxide until $1,000 \mathrm{~nm}$, given its low content, such behavior could be similar to that of Quartzipsamments (Valeriano et al., 1995). The Bt horizon seems to fit into the same pattern, although less sandy, with more pronounced features and lower reflectance intensity. The superficial horizon (Ap), likewise sandy, with a maximum reflectance factor around $59 \%$, has its features masked by organic matter (Figure 4c) and has a type 2 behavior standard (Table 1 and Figure 1).

\section{Organic matter, texture and mineralogy effects on the soil reflectance}

Among the different profiles, it can be observed that whenever there is an increase in organic matter, the reflectance intensities decrease and the curve aspect 


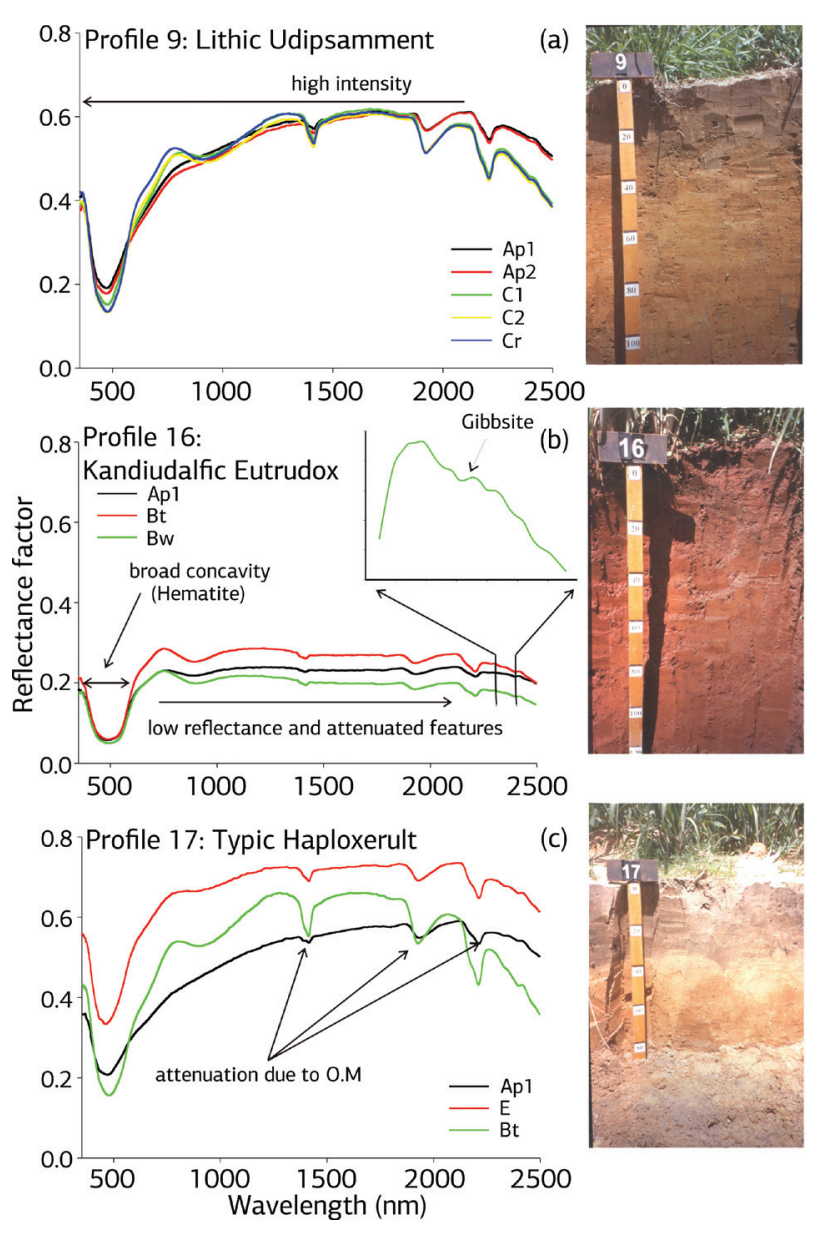

Figure 4. Spectral behavior of the soil classes: Lithic Udipsamment (a), Kandiudalfic Eutrudox (b), and Typic Haploxerult (c), and their respective horizons; Ap: A horizon with pedoturbation (numeric suffixes indicate subdivisions); E: mineral horizon with clay removal; $\mathrm{Bw}$ and $\mathrm{Bt}$ : $\mathrm{B}$ horizon with intense alteration and with clay accumulation, respectively; $\mathrm{Cr}$ : $\mathrm{C}$ horizon (unconsolidated material) with saprolite (SANTos et al., 2005).

becomes rectilinear (Figure 5a). These results confirm the findings described in the literature where organic matter in the soil absorbs electromagnetic energy and modifies the spectrum geometry (Demattê et al., 2003). The shape acquired by the spectrum with the addition of organic matter helps in identifying the effect of the iron oxide absorption by creating a concavity at $850 \mathrm{~nm}$.

The granulometric variation of the soil, as mentioned earlier, has an influence on the descriptive aspects of the spectral data. Sandier soils reflect more electromagnetic energy and show spectra with an ascending shape up to approximately $1,700 \mathrm{~nm}$ and thereafter a descending shape within the rest of the infrared spectrum. With increasing clay content, the albedo intensity decreases and the spectra take a flat shape (Figure 5b) (Demattê and Garcia 1999). As a matter of fact, the relation between the textural characteristics and spectral forms strengthen the possibility to quantify the clay content through mathematical models, as stated by SORENSEN and DalsgaArd (2005).

Soils that are less weathered with a high ki index show a predominantly 2:1 mineralogy, while soils with a low ki index are more developed and can have kaolinitic or oxidic mineralogy. As previously observed, the absorption features, principally at $1,900 \mathrm{~nm}$ and $2,200 \mathrm{~nm}$, indicate a presence of 2:1 and 1:1 minerals, depending on their descriptive aspects. In this case, when the ki index increases, these features become more pronounced, mainly because of the 2:1 mineralogy (Figure 5c). More weathered soils, indicated by their low ki index, show less distinct absorption features.

The effects of the iron oxides and their relation to the color variation in the soils can also be found through the descriptive aspects of the spectral data (Figure 5d). Yellowish soils show a spectral behavior similar to that of goethite, with absorption features of higher reflectance intensity, however more narrow at $480 \mathrm{~nm}$ and less deep at $750 \mathrm{~nm}$. In the reddish soils, with a predominance of hematite, the bands were less intense with bigger amplitude at $480 \mathrm{~nm}$ and deeper at $750 \mathrm{~nm}$ (FonTes and Carvalho, 2005).

\section{Spectral behavior of soils along the landscape and its relation with classification}

The spectral evaluation of the soils along a toposequence can help determining the soil limits and consequently their mapping. According to this idea, three representative soil classes were chosen in the study area: Kandiudalfic Eutrudox (Nitossolo Vermelho Eutroférrico latossólico - NVef) (Profile 4); Typic Hapludoll (Chernossolo Háplico Órtico típico - MXo) (Profile 5) and Lithic Eutrudept (Cambissolo Háplico Eutroférrico léptico - CXef) (Profile 6). The spectral curves for these soil classes, obtained in the laboratory with soil samples collected in situ, with their respective position in the landscape, can be seen in Figure 6a.

The Kandiudalfic Eutrudox (NVef) is located at the highest position in the landscape and characterized by good drainage, clayey to heavy clayey texture, high content of iron oxide, eutrophic character and a mineralogy containing kaolinite, iron and aluminum oxides. The spectral curves show a well developed soil behavior with a broad concavity, represented by hematite, as well as the rest of the features with lower intensity, corresponding to 2:1 clay minerals and a more pronounced feature with kaolinite characteristics (Figure 6b). This soil tends to show homogeneous spectral curves for all horizons, with reducing reflectance intensity in function of depth but maintaining the same absorption features (Demattê et al., 2001; 2004). 


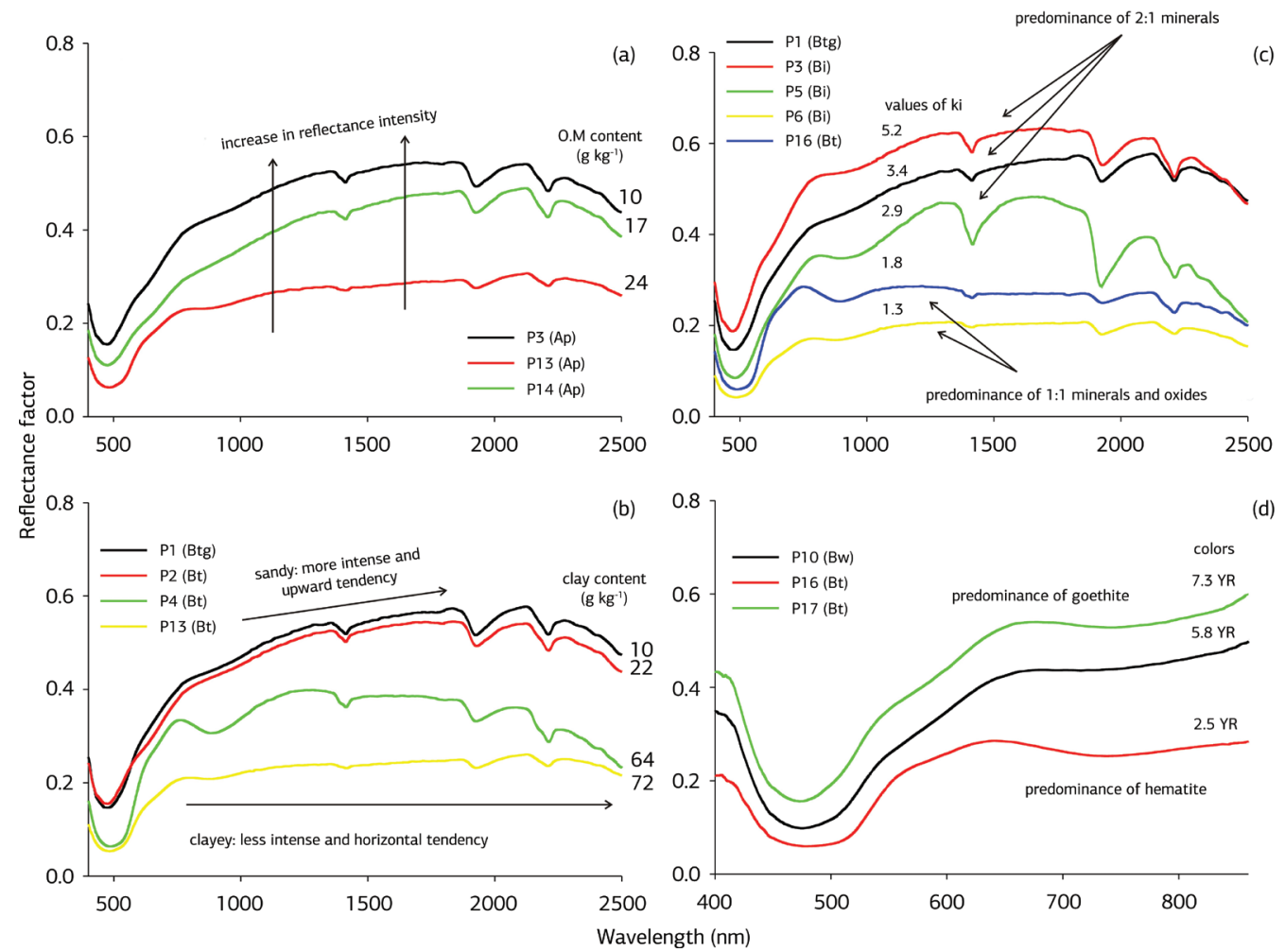

Figure 5. Influence of the soil attributes in the soil spectra: organic matter (a); granulometry (b); Ki index (c); iron oxides (d); P: studied profile, Ap: A horizon with pedoturbation; Bi, Bw, Bt and Btg: incipient B horizon, with intense alteration, with clay accumulation and gley, respectively (SANTOS et al., 2005).
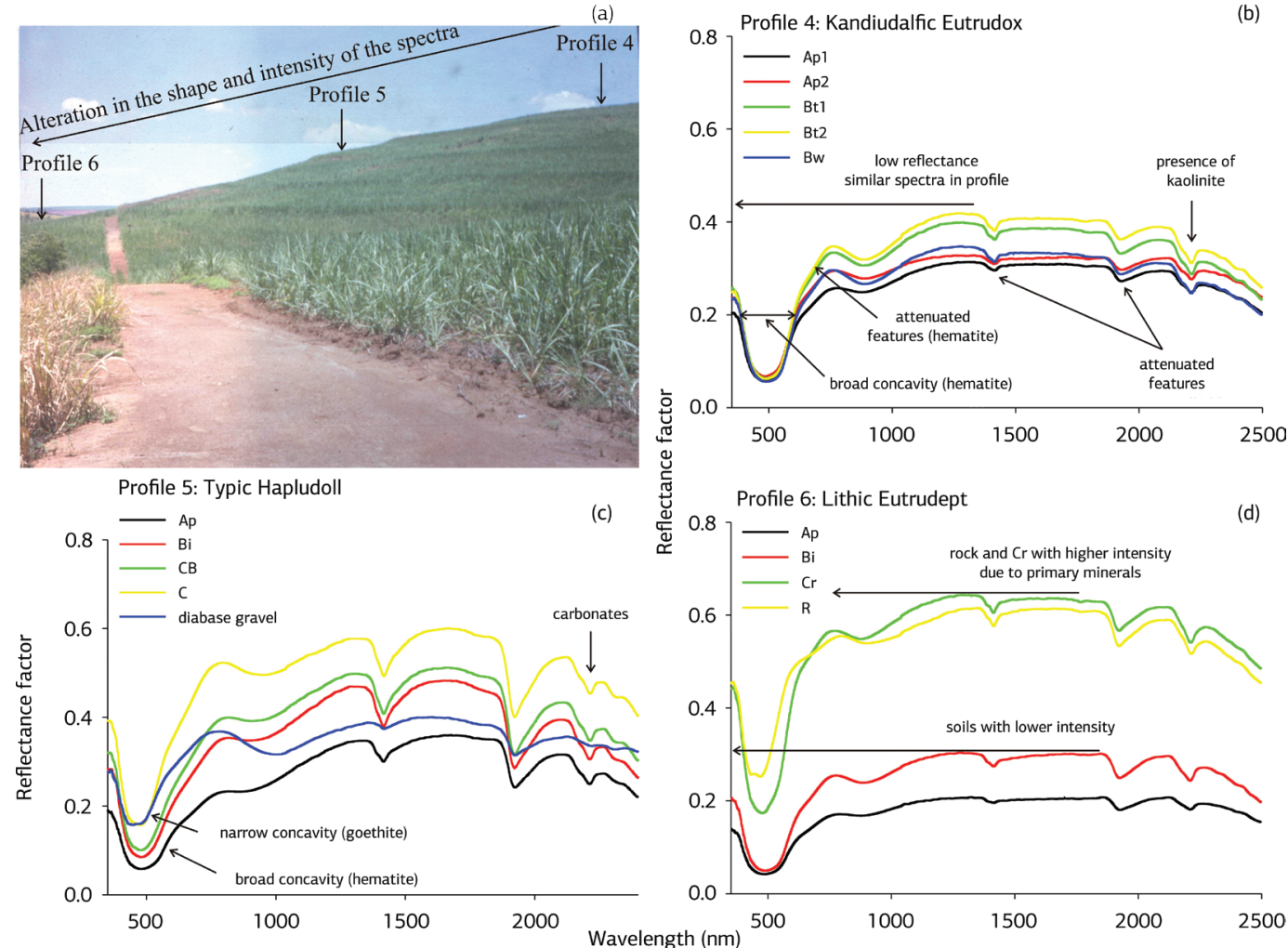

Figure 6. Spectra of three soil profiles (b-d) sampled in different positions in the toposequence (a), where Ap: A horizon with pedoturbation (numeric suffixes indicate subdivisions); $\mathrm{Bi}, \mathrm{Bw}, \mathrm{Bt}$ : incipient $\mathrm{B}$ horizon, with intense alteration and with clay accumulation, respectively; $\mathrm{CB}$ and Cr: C horizon (unconsolidated material) with some characteristics of B horizon and with saprolite, respectively; R: bedrock (SANTOS et al., 2005). 
The Typic Hapludoll (MXo), localized in an intermediate position in the landscape, has a great content of 2:1 minerals (ki index around 2.9) and a differentiated texture with depth, giving distinct spectral curves between horizons regarding intensity and form when compared to the Kandiudalfic Eutrudox (Figure 6c). The high intensity of the absorption features, corresponding to the 2:1 minerals, gives this profile the characteristics of a less weathered soil. The same can be said for the Lithic Eutrudept (CXef), which presents poorly developed subsurface horizons and close to the parent material with a high albedo, different from the surface horizons that are influenced by organic matter.

\section{CONCLUSION}

The hypothesis of the study was confirmed. Each soil class shows distinct classification characteristics due to the nature of the analytical and morphological data that in turn are closely related to the descriptive spectral data.

\section{REFERENCES}

ALMEIDA, F.F.M.; MELO, M.S. A bacia do Paraná e o vulcanismo mesozóico. In: ALMEIDA, F.F.M.; HASUI, Y.; PONÇANO, W.L.; DANTAS, A.S.L.; CARNEIRO, C.D.R.; MELO, M.S.; BISTRICHI, C.A. Mapa geológico do Estado de São Paulo. São Paulo: IPT, 1981. Cap. 4, p. 46-81.

BEN-DOR, E.K.; PATKIN, K.; BANIN, A.; KARNIELI, A. Mapping of several soil properties using DAIS-7915 hyperspectral scanner data. A case study over clayey soil in Israel. International Journal of Remote Sensing, v.23, p.1043-1062, 2002.

CAMARGO, O.A.; MONIZ, A.C.; JORGE, J.A.; VALADARES, J.M. Métodos de análise química, mineralógica e física de solos do IAC. Campinas: Instituto Agronômico de Campinas, 1986. 94 p. (Boletim Técnico, 106)

COZZOLINO, D.; MORÓN, A. The potential of near-infrared reflectance spectroscopy chemometrics to predict soil organic carbon fractions. Soil and Tillage Research, v.85, p.78-85, 2006.

DEMATTÊ, J.A.M.; GARCIA, G.J. Alteration of soil properties through a weathering sequence as evaluated by spectral reflectance. Soil Science Society of American Journal, v.63, p.327-342, 1999.

DEMATTÊ, J.A.M.; DEMATTÊ, J.L.; CAMARGO, W.P.; FIORIO, P.R.; NANNI, M.R. Remote sensing in the recognition and mapping of tropical soils developed on topographic sequences. Mapping Sciences and Remote Sensing, v.38, p.79-102, 2001.

DEMATTÊ, J.A.M.; EPIPHANIO, J.C.; FORMAGGIO, A.R. Influência da matéria orgânica e de formas de ferro na reflectância de solos tropicais. Bragantia, v.62, p.451-464, 2003.
By the methodology of clustering the spectra according to the behavioral standards, the sandy soils are classified mainly as type 2 and 4, while the soils with higher content of clay are of type 1 . However, a more detailed analysis of the spectral curves with respect to shape, features and absorption intensity gives better information about the soil samples than by clustering alone.

The evaluation of the spectral data of soil samples from the surface and subsurface horizons permits to discriminate the profile's analytic variability, supporting the soil discrimination and classification.

There is a strong relationship between the degrees of soil weathering and the spectral information. The sandy soils, developed over sandstones, show the highest reflectance intensities with ascending spectral curves, contrary to the clayey soils from basic rocks. Using the descriptive aspects of the spectra, it is possible to detect the influence of the presence of 1:1 minerals (kaolinite and gibbsite), 2:1 minerals, iron oxides (hematite and goethite) and organic matter in soil.

DEMATTÊ, J.A.M.; CAMPOS, R.C.; ALVES, M.C.; FIORIO, P.R.; NANNI, M.R. Visible-NIR reflectance: a new approach on soil evaluation. Geoderma, v.121, p.95-112, 2004.

EMPRESA BRASILEIRA DE PESQUISA AGROPECUÁRIA - EMBRAPA. Centro Nacional de Pesquisa de Solos. Sistema Brasileiro de Classificação de Solos. 2.ed. Rio de Janeiro: Embrapa Solos, 2006. 306p.

FONTES, M. P.F.; CARVALHO, A. Color attributes and mineralogical characteristics, evaluated by radiometry, of highly weathered tropical soils. Soil Science Society of American Journal, v.69, p.1162-1172, 2005.

FORMAGGIO, A.R.; EPIPHANIO, J.C.; VALERIANO, M.M.; OLIVEIRA, J.B. Comportamento espectral (450-2.450 nm) de solos tropicais de São Paulo. Revista Brasileira de Ciência do Solo, v.20, p.467-474, 1996.

KOSMAS, C.S.; CURI, N.; BRYANT, R.B.; FRANZMEIER, D.R. Characterization of iron oxide minerals by second-derivative visible spectroscopy. Soil Science Society of American Journal, v.48, p.401-405, 1984.

MADEIRA NETTO, J.S. Spectral reflectance properties of soil. Photo Interpretation, v.34, p.59-70, 1996.

MOORE, D.M.; REYNOLDS, R.C. X-ray diffraction. In: MOORE, D.M.; REYNOLDS, R.C. (Ed.). X-Ray diffraction and the identification and analysis of clay minerals. New York: Oxford University Press, 1997. chap. 3, p. 61-103.

ODLARE, M.; SVENSSON, K.; PELL, M. Near infrared reflectance spectroscopy for assessment of spatial soil variation in an agricultural field. Geoderma, v.126, p.193-202, 2005. 
SANTOS, R.D.; LEMOS, R.C.; SANTOS, H.G.; KER, J.C.; ANJOS, L.H.C. Manual de descrição e coleta de solo no campo. 5.ed. Viçosa: Sociedade Brasileira de Ciência do Solo, Centro Nacional de Pesquisa de Solos, 2005. 92p.

SCHEINOST, A.C.; SCHWERTMANN, U. Color identification of iron oxides and hydroxysulfates: Use and limitations. Soil Science Society of American Journal, v.63, p.1463-1471, 1999.

SHEPHERD, K.D.; WALSH, M.G. Development of reflectance spectral libraries for characterization of soil properties. Soil Science Society of American Journal, v.66, p.988-998, 2002.

SHERMAN, D.M.; WAIT, T.D. Electronic spectra of $\mathrm{Fe}^{+3}$ oxides and oxides hydroxides in the near IR to near U.V. American Mineralogist, v.70, p.1262-1269, 1985.

SORENSEN, L.K; DALSGAARD, S. Determination of Clay and Other Soil Properties by Near Infrared Spectroscopy. Soil Science Society of American Journal, v.69, p.159-167, 2005.
STONER, E.R.; BAUMGARDNER, M.F. Characteristics variations in reflectance of surface soils. Soil Science Society of American Journal, v.45, p.1161-1165, 1981.

VALERIANO, M.M.; EPIPHANIO, J.C.N.; FORMAGGIO, A.G.; OLIVEIRA, J.B. Bidirectional reflectance factor of 14 soil classes from Brazil. International Journal of Remote Sensing, v.16, p.113-128, 1995.

VISCARRA ROSSEL, R.A.; WALWORT, D.J.J.; MCBRATNEY, A.B.; JANIK, L.J.; SKJESMSTAD, J. O. Visible near infrared or combined diffuse reflectance spectroscopy for simultaneous assessment of various soil properties. Geoderma, v.131, p.59-75, 2006.

VITORELLO, I.; GALVÃO, L.S. Spectral properties of geological materials in the 400 to $2500 \mathrm{~nm}$ range: review of applications to mineral exploration and lithologic mapping. Photo Interpretation, v.34, p.77-99, 1996. 